\title{
SFRP4 wt Allele
}

National Cancer Institute

\section{Source}

National Cancer Institute. SFRP4 wt Allele. NCI Thesaurus. Code C52936.

Human SFRP4 wild type allele is located in the vicinity of 7p14.1 and is approximately 11 $\mathrm{kb}$ in length. This allele, which encodes secreted frizzled-related protein 4 , is involved in both the initiation of the Wnt protein-mediated signaling pathway, and the regulation of apoptotic gene expression. 